\title{
The calamity of eruptions, or an eruption of benefits? Mt. Bromo human-volcano system a case study of an open-risk perception
}

\author{
S. Bachri ${ }^{1,3}$, J. Stötter ${ }^{1}$, M. Monreal ${ }^{1}$, and J. Sartohadi ${ }^{2}$ \\ ${ }^{1}$ Institute of Geography, Innsbruck University, Innsbruck, Austria \\ ${ }^{2}$ Department of Geography and Environmental Science, Faculty of Geography, Gadjah Mada University, \\ Yogyakarta, Indonesia \\ ${ }^{3}$ Department of Geography, Faculty of Social Science, State University of Malang, Malang, Indonesia \\ Correspondence to: S. Bachri (syamsul.geography@gmail.com)
}

Received: 28 May 2014 - Published in Nat. Hazards Earth Syst. Sci. Discuss.: 27 August 2014

Revised: 9 January 2015 - Accepted: 11 January 2015 - Published: 16 February 2015

\begin{abstract}
In this paper we investigate the question not of how, but why people actively choose to live with continued exposure to considerable hazard. A field survey of the human-volcano interaction at Bromo Volcano was based on semi-structured interviews and focus group discussions. The recorded interviews were transcribed and analysed according to recurrent themes in the answers. Findings from field investigation were then confronted with previous existing concepts of human exposure to natural hazards. The result shows that the interaction between humans and the volcanic environment at Bromo volcano is multifaceted and complex. The Tengger people choose - rather than being forced - to live with volcanic hazards. They are not only exposed to its negative consequence, but also enjoy benefits and opportunities of physical, spiritual and socio-cultural nature that arise within the human-volcanic system. Following this perspective, the concept of risk itself must be revisited and expanded from a one-sided focus on hazardous processes to a more holistic view of risk that includes the various positive aspects that pertain to the entire system. The development of a generic human-volcanic system model could provide the basis for the development of an open-risk concept.
\end{abstract}

\section{Introduction}

Volcanic activities almost invariably affect human lives. More than half a billion people live in the direct vicinity of volcanoes and are thus exposed to hazard (Tilling, 2005). Often places of serene beauty and abundant with diverse natural resources, are located adjacent to, or even within, highly active volcanic zones. Indonesia, situated at the intersection of three active tectonic plates (the Eurasian, Australian and $\mathrm{Pa}$ cific plates), at the aptly named "ring of fire", boasts 129 active volcanoes and 271 eruption points (Abidin et al., 2004; Pratomo, 2006; Zaennudin, 2010) (Fig. 1). Approximately 3.3 million people in Indonesia live in areas categorized as volcanic regions (CVGHM, 2010). In Java Island, where 120 million people live in the shadow of 30 volcanoes, more than 140000 fatalities occurred due to volcanic eruptions in the last 500 years (Surono, 2013).

With its periodical eruptions Mt. Bromo on Java Island is one of the most active volcanoes in Indonesia. The communities living around the mountain have evolved a unique culture that is inspired by the volcano as central symbol and deity. The people of Mt. Bromo - the Tenggerese - are even named after the ancient Tengger Caldera, which today contains Mt. Bromo. They count approximately 600000 and are descendants of the Majapahit princes of Java. As observed elsewhere around the world and throughout history (Duncan et al., 1981; Fisher et al., 1997; Heijmas, 2001; Kelman and Mather, 2008) even severe eruptions like those of Mt. Bromo in 2010 have not deterred people from returning and continuing to live with a considerable risk of hazard. Despite suffering from devastating impacts of volcanic eruptions people decide to live and adapt to the recurring phenomenon.

From a classical deterministic scientific perspective, with a clear focus on the volcano, its hazards and related potential negative impacts on society, these latter statements - people choosing to live with objective danger - may cause sur- 


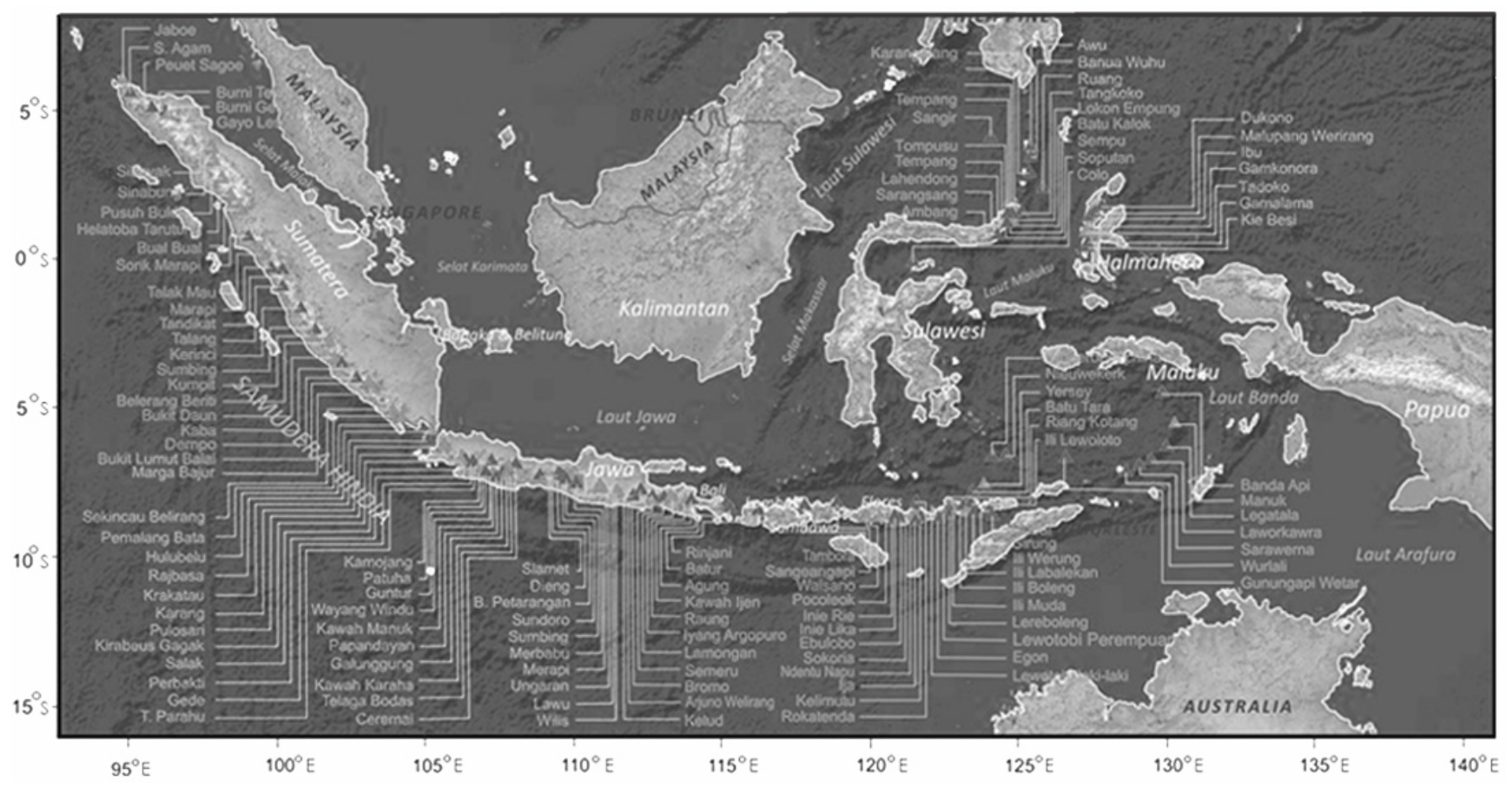

Figure 1. Distribution of active volcanoes in Indonesia (Surono, 2013).

prise and disbelief (Siswowidjoyo et al., 1997; Itoh et al., 2000; Andreastuti, 2000; van Rotterdam-Los et al., 2008; De Bélizal et al., 2012; Mei et al., 2013). Two aspects of the conventional approach have to be highlighted here: (i) from a theoretical point of view, volcano and human society are conventionally understood as two dichotomous systems, in a relationship in which the volcano and its activities determine societal behaviour distinctly; (ii) the focus lies on investigating the negative, threatening impacts of a volcano on society and how people live and cope with this situation.

We want to question the merit of this deterministic approach and determine whether it produces any progress in terms of (a) a deeper system understanding and (b) an application in disaster risk management. In recent decades, on both the theoretical and the practical side a change in thinking has occurred. The separation of humankind and nature, respectively society and environment (see e.g. Descartes, 1641; Popper, 1972; Latour, 1993; Zierhofer, 2002), gives way to the idea of Earth being a human-environment system, in which society and nature are inseparably interlinked by manifold processes (see e.g. Fischer-Kowalski and Weisz, 1999; Wardenga and Weichhart, 2006). Besides these theoretical reflections, it was indeed very application-driven research that concluded that all grand global challenges (e.g. climate change, resource scarcity, globalization) can only be understood and targeted solution can only be tailored when there is a holistic view of society and nature. The Earth system must be understood as a human-environment system in which both sides are driving and driven at the same time.
In this paper we do not investigate the question of how, but why people live with continued exposure to considerable hazard. Expanding upon the previously proposed explanations that this behaviour is due to a lack of hazard knowledge (Gregg et al., 2004; Bird et al., 2010), a lack of alternatives (Wisner et al., 2004; Lavigne et al., 2008), or that people may be forced to do so based on their marginalized social status (Bryant, 1998), we propose that risk perception and risk tolerance can only be fully understood when investigating within a framework of human-environment systems in general, and the human-volcano system specifically.

The human-volcano system that we present here allows for an analysis that goes beyond the narrow focus of volcanic eruptions and lends itself to a more holistic appreciation of volcanic risk as presenting both hazards and opportunities. Based on a case study from Mt. Bromo, we will highlight the need to revise common risk concepts and to include the assessment of upside risks, or opportunities, that may off-set exposure to negative effects. We will conclude that an open-risk concept is not only necessary to understand decision-making processes, but will have deep implications for disaster risk reduction and risk management strategies in the context of volcanism and for their general progression. In order to gain a comprehensive understanding of the natural and societal ramification of living with volcanic hazard risk, we will first lay out the physical characteristics of eruption activity of Mt. Bromo and then contextualize this within a human-volcano system approach. 


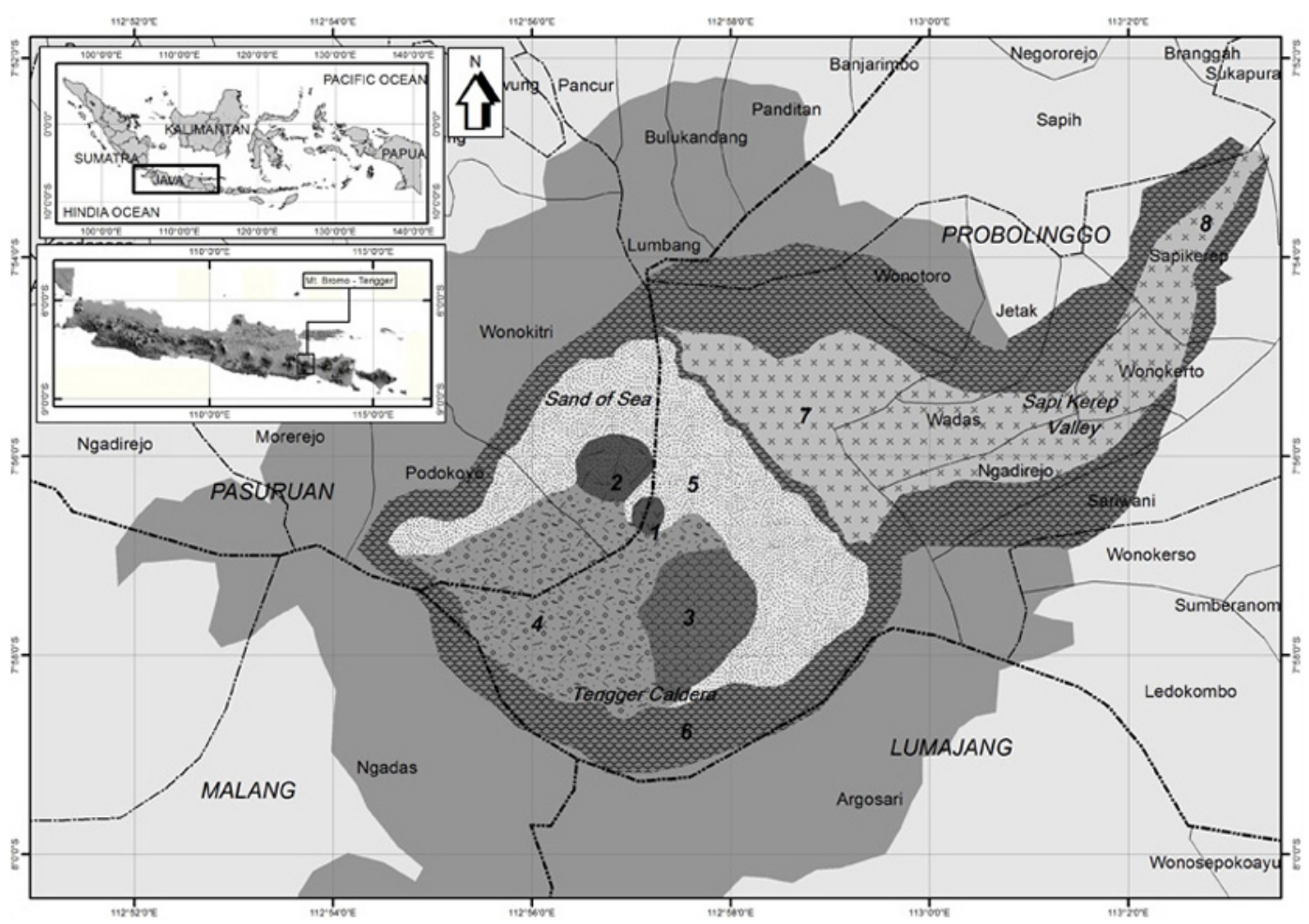

Figure 2. Bromo Volcano and its landforms: (1) Gunung Bromo and its crater; (2) a Strombolian cone, Gunung Batok; (3) complex of rest volcanic cone (G. Kursi); (4) complex of rest volcanic cone (G. Widodaren) and Segara Wedi; (5) Sand of Sea ; (6) Tengger caldera formation (upper and middle slope); (7) foot slope of Tengger caldera (Sukapura Barranco); (8) Sapi Kerep outlet valley (interpretation from SRTM Image and field survey.)

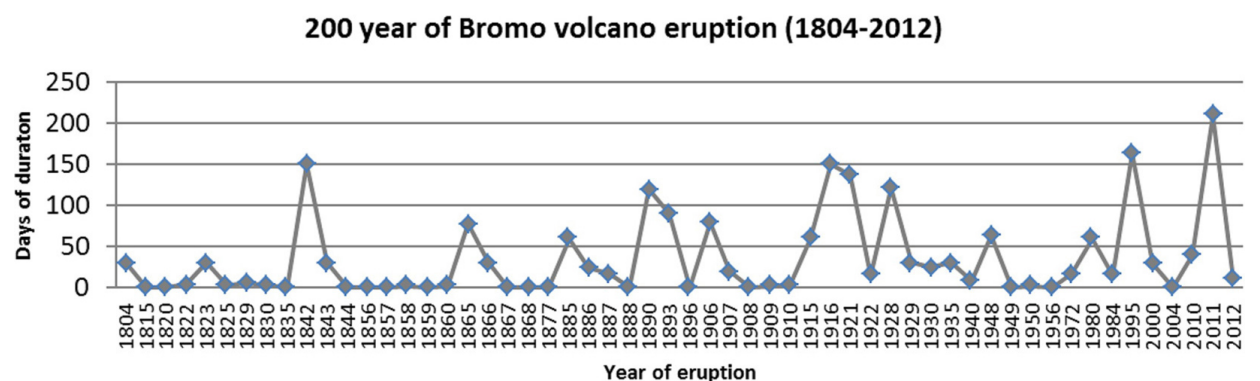

Figure 3. Year and duration (days) of Mt. Bromo eruption in a 200-year period (for 1804-2010, CVGHM 2010; and for 2011-2012, Field survey, 2012).

\section{Mt. Bromo characteristics and eruption activity}

Mt. Bromo (2392 m) is shared by four districts in East Java Indonesia, namely Probolinggo, Malang, Pasuruan and Lumajang. Mt. Bromo is an active volcano located inside the much larger and older Tengger caldera. The diameter of the caldera is $9 \mathrm{~km}$ stretching from north to south and was formed by the ancient Tengger Volcano during the late Pleistocene and early Holocene (Gerven and Pichlert, 1995; Solikhin et al., 2012). Widely distributed tephra deposits (predominantly coarse ash) make up the famous Sand Sea caldera (Fig. 2). The frequent eruption activity of Mt. Bromo is well recorded. Data show that Bromo has erupted at least 56 times since 1804, ranging from mild to moderate eruptions with duration between 1 and 270 days (Fig. 3) (CVGHM, 2010). According to CVGHM, Bromo Volcano is an active volcano which has erupted many times on a scale of VEI (Volcanic Eruption Index) level 2.

The last eruption of Mt. Bromo in 2010 was unusual as it continued for 9 months, the longest period in its recorded history (Bachri et al., 2013a). The eruption type had changed from previous vulcanian to Strombolian activity. These were phreatomagmatic eruptions, producing materials dominated by fine to coarse ash. The first eruption occurred 
Table 1. Chronology of Bromo eruption in 2010 (CVGHM, 2010).

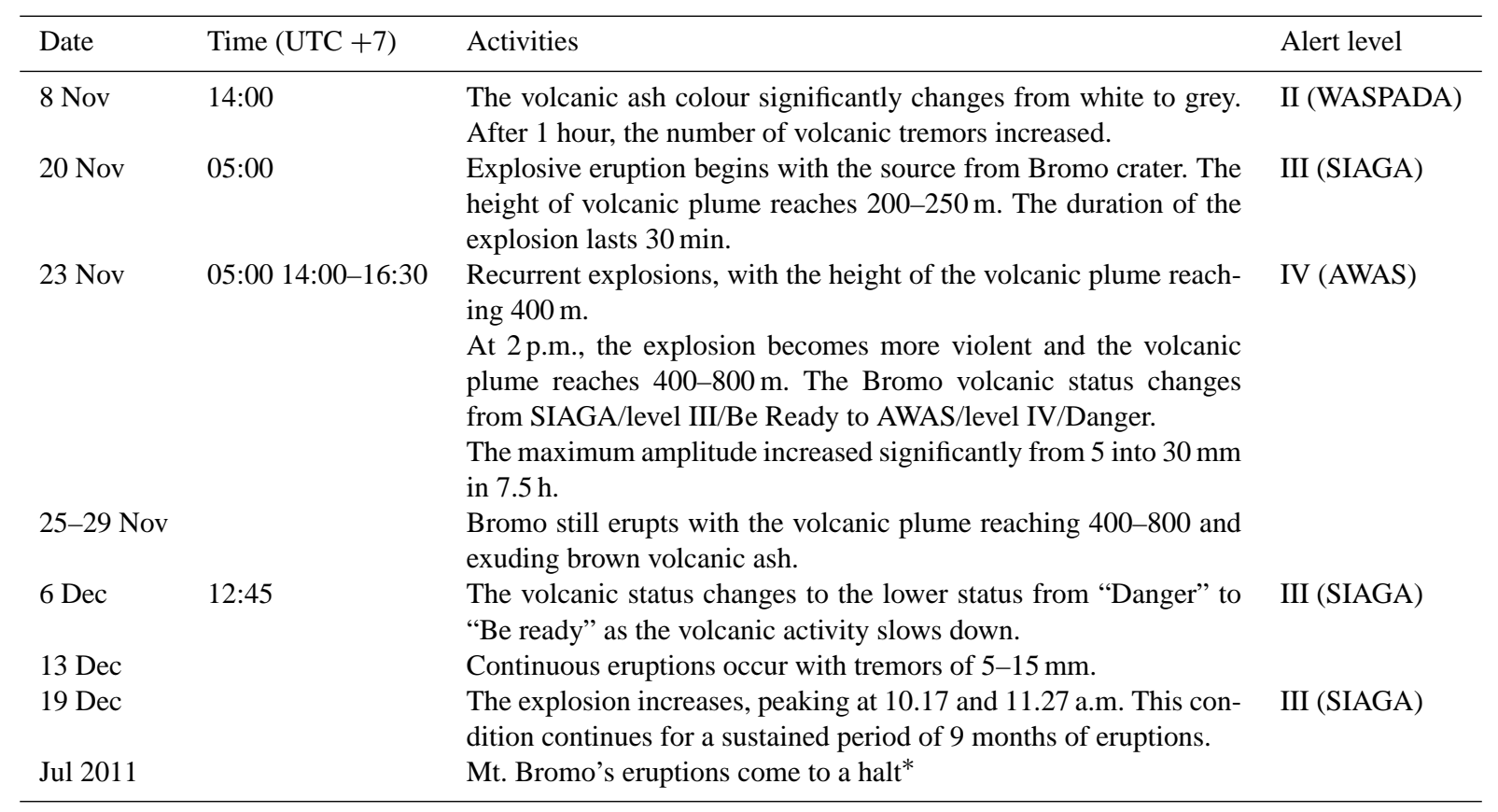

* Data from field survey, WASPADA: "Be careful", SIAGA: "Be ready", AWAS: "Danger".

on 20 November 2010 with the volcanic plume reaching a height of $250 \mathrm{~m}$. On 23 November, a second, larger eruption began, producing a plume the height of which ranged from 400 to $1000 \mathrm{~m}$ covering the entire Bromo area (Table 1). By December 2010, volcanic ash fall occurred in tens of kilometres toward north, east and south of Mt. Bromo. During the following 9 months, ash and lapilli was deposited up to $50 \mathrm{~km}$ from the volcano; fine ash even reached Surabaya city, $90 \mathrm{~km}$ away. Furthermore, volcanic bombs with sizes of $1-3 \mathrm{~cm}$ impacted up to a distance of $2.2 \mathrm{~km}$ from the crater.

The total economic loss due to the 2010 eruptions amounts to more than IDR 154 billion ( USD 15.5 million) reflecting the severe affects on agriculture, tourism activity and loss of property (BPBD, 2011). Indirect and difficult to monetize impacts also caused a decline in the water availability, disrupted electricity supply and transportation, diminished trading activity and led to health problems. A total of 70000 , mostly agriculture-dependent people distributed over 33 villages were affected by Mt. Bromo's eruptions (BPS, 2011). The 2010 eruptions of Mt. Bromo were the worst ever recorded and among the most impacting volcanic eruptions in recent time.

\section{Materials and methods}

In order to reach a comprehensive understanding of humanvolcano interaction, this study bridges between natural and social science. Thus, the scope of our research objective, which includes physical and social aspects, is reflected in both research methodology and style of analysis, which tends from physical-geographical issues as far as to ethnographic observations. In investigating the human-volcano interaction within the Bromo region this study draws on (1) existing statistic data of the research area (2) semi-structured interview and (3) focus group discussion. The first phase of the field work took place in February-March 2012 with the purpose to capture data related to Bromo Volcano. The second phase of field work (July-September 2012) involved semistructured interviews with key persons at the village level. During the third phase, focus group discussions were held in February and March 2013. While the secondary data collection includes quantitative aspects, the main focus of the field research was qualitative in nature.

\subsection{Existing statistic data of the research area}

For an analysis of the environmental condition of Bromo Volcano and in order to profile adjacent communities we compiled various data sets. The eruption monitoring data and volcanic hazard maps were obtained from the Centre for Volcanology and Geological Hazard Mitigation (CVGHM) in Bandung, Java. Data related to damage and loss assessments (DALA) were collected to examine eruption impacts on both physical and societal environment of each village with particular focus on the 2010 Bromo eruptions. These data were kindly supplied by the regional disaster management agency Badan Penanggulangan Bencana Daerah (BPBD) of Probolinggo city, East Java Province. During data collection also key informants and communities at risk were profiled and 
identified through abstracting data from demographic statistics at the village level.

\subsection{Semi-structured interviews with key informants}

During July-September 2012, semi-structured interviews were conducted with representatives of local communities and government officials in four districts (Pasuruan, Probolinggo, Malang and Lumajang) surrounding Mt. Bromo in order to examine the human-volcano relationship within the Bromo area in general and investigate local knowledge related to hazard, risk perception and adaptation strategies to volcanic risk specifically. Only such villages were considered which experienced impacts of the eruption, according to secondary data information. Interviews took place in two villages in Pasuruan (Wonokitri and Tosari), four villages in Probolinggo (Ngadirejo, Ngadisari, Wringinanom, Sumber), one village in Malang (Ngadas) and one village in Lumajang districts (Ranupane) (Fig. 4). A total of 14 interviews were conducted. Informants were village officers, farmers, teachers, dukun (spiritual leaders) and three authorized staff from BPBD Probolinggo city and CVGHM (Table 2). Interviews were loosely structured, starting from the physical impacts to social and cultural effects. However, the informants were encouraged to answer freely and not to be limited to the guiding question (Table 3 ). The objective was to initiate various members of the Bromo community (the Tenggerese) to share their experience of Mt. Bromo in an unbiased way and deliberately without exclusive focus on eruptions or negative impacts only. Discernible from Table 3, direct questions that could lead to simple positive and negative answers were avoided. Questions pertained to hazard understanding, familiarity with volcanic risks and dread factors as well as to the opportunities provided by Mt. Bromo and the general attitude towards the volcano and its role in local culture. All interviews were shaped to the local context and were conducted in Indonesian and Javanese language. Interviews were recorded by video recorder.

\subsection{Focus group discussion}

Following the semi-structured interviews of phase I and II of the field work we conducted a focus group discussion (FGD) in phase III. With the FGD we hoped to gain deeper insights by giving the participating group an opportunity to express themselves in their own words and confront and compare their individual perceptions with other members of the community. We chose the community of Ngadirejo for the FGD, since our analysis of phases I and II showed that this village was most negatively exposed to the recent eruptions. The discussion was initiated with similar questions as were used to structure the interviews in phase II (Table 3). There were eight participants to the FGD consisting of farmers, village officials, village heads and youth representatives (Table 2).

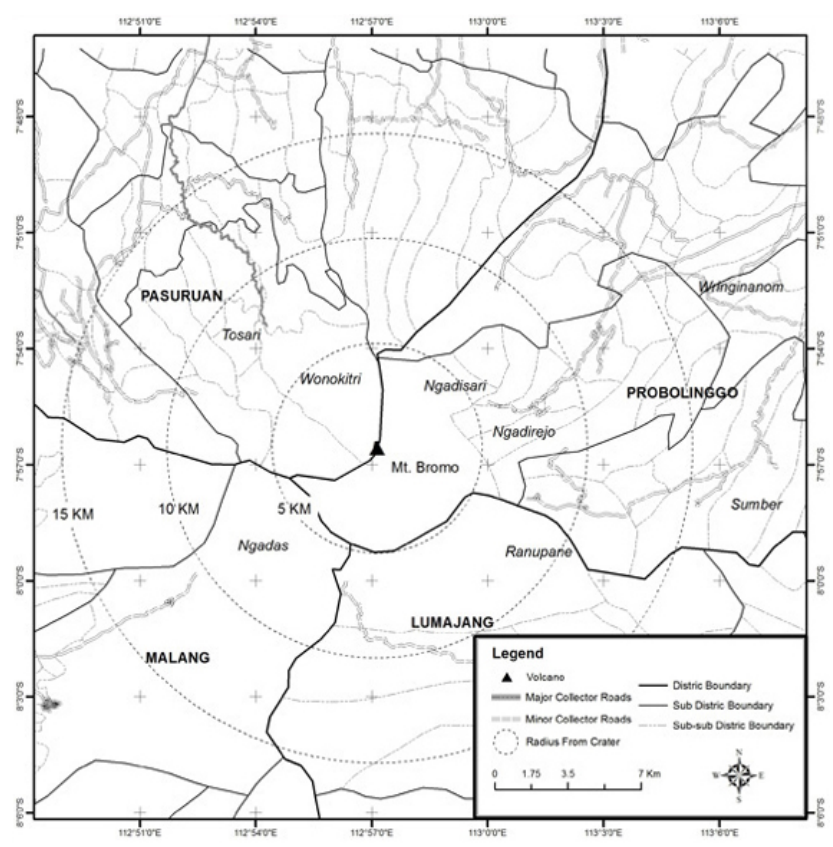

Figure 4. Map of surveyed villages in Bromo Volcano area.

Semi-structured interviews and FGD were transcribed and analysed according to recurrent themes in the answers. Results are presented in narrative form and analysed in view of existing research of habitation in volcanic areas as well as prevailing concepts of risk research.

\section{Towards a human-volcanic system - the case of Mt. Bromo volcano}

In the following paragraphs, we present the results of our findings on the interaction between volcanic eruptions, local knowledge and risk in our study area in the form of a humanvolcano system of the Mt. Bromo area (Fig. 5). Therein the various interactions between community and volcano are shown. Both physical and social aspects are considered.

\subsection{Environmental condition (Bromo volcanic eruption in 2010)}

The four major hazards produced by Mt. Bromo in 2010 were tephra fall/ballistics, volcanic mud flow, landslides and gas emission. Form and impact from these sources of hazards varied from negligible to severe. Tephra fall comprised volcanic ash, blocks and bombs (see Fig. 5). Areas inside the Tengger caldera were exposed to angular blocks and rounded bombs (Zaennudin, 2011). In addition, volcanic ash and lapilli were distributed throughout the surrounding area depending on wind direction, morphology and weight of the material. For instance, regions with an elevation over $2000 \mathrm{~m}$ m.s.l. were relatively safer from volcanic ash due to the protection by the caldera wall (Bachri et al., 2013b). 
Table 2. Survey method at village around Bromo Volcano.

\begin{tabular}{|c|c|c|c|c|}
\hline & Probolinggo District & Malang District & Pasuruan District & Lumajang District \\
\hline Village & $\begin{array}{l}\text { Ngadisari, Sumber, } \\
\text { Wringinanom, Ngadirejo } 1\end{array}$ & Ngadas & Wonokitri, Tosari & Ranupane \\
\hline $\begin{array}{l}\text { Justification of } \\
\text { surveyed village }\end{array}$ & \multicolumn{4}{|c|}{$\begin{array}{l}\text { - Close to the crater (CVGHM, 2010) } \\
\text { - Inhabited by Tengger community (indigenous Bromo community) (BPS, 2011) } \\
\text { - Categorized as affected village by Bromo eruption (BPBD, 2011) }\end{array}$} \\
\hline $\begin{array}{l}\text { Technical survey } \\
\text { approach }\end{array}$ & $\begin{array}{l}\text { Secondary data collection, } \\
\text { semi-structured interview }\end{array}$ & $\begin{array}{l}\text { Secondary data collection, } \\
\text { semi-structured interview }\end{array}$ & $\begin{array}{l}\text { Secondary data collection, } \\
\text { semi-structured interview }\end{array}$ & $\begin{array}{l}\text { Secondary data } \\
\text { collection, } \\
\text { semi-structured } \\
\text { interview }\end{array}$ \\
\hline $\begin{array}{l}\text { Date of survey } \\
\text { (month/year) }\end{array}$ & $\begin{array}{l}\text { Feb-Mar } 2012 \\
\text { Jul-Sep } 2012 \\
\text { Feb-Mar } 2013^{1}\end{array}$ & $\begin{array}{l}\text { Feb-Mar } 2012 \\
\text { Jul-Sep } 2012\end{array}$ & $\begin{array}{l}\text { Feb-Mar } 2012 \\
\text { Jul-Sep } 2012\end{array}$ & $\begin{array}{l}\text { Feb-Mar } 2012 \\
\text { Jul-Sep } 2012\end{array}$ \\
\hline $\begin{array}{l}\text { Interviewed people } \\
\text { and their function }{ }^{2}\end{array}$ & $\begin{array}{l}\text { - Ngadisari: } \\
\text { Bapak Ari (dukun) } \\
\text { - Ngadirejo: Bapak Yudi } \\
\text { (head of village), } \\
\text { Bapak Wahyu } \\
\text { (head of KSB), } \\
\text { Bapak Rudi } \\
\text { (farmer and village } \\
\text { official) } \\
\text { Ibu Rita (farmer) } \\
\text { - Sumber: Bapak Budi } \\
\text { (farmer) } \\
\text { - Wringinanom: Bapak } \\
\text { Kirno (head of village) }\end{array}$ & $\begin{array}{l}\text { - Ngadas: Bapak Jarwo } \\
\text { (head of village), } \\
\text { - Bapak Gunawan } \\
\text { (farmer and village } \\
\text { official) }\end{array}$ & $\begin{array}{l}\text { - Wonokitri: Ibu Ambar } \\
\text { (head of village), Bapak } \\
\text { Sutrisno (dukun), Ibu } \\
\text { Yanti (teacher), } \\
\text { - Tosari: Ibu Erna (govern- } \\
\text { ment official of Agricul- } \\
\text { ture Department) }\end{array}$ & $\begin{array}{l}\text { - Ranupane: } \\
\text { Bapak Supardi } \\
\text { (farmer) }\end{array}$ \\
\hline
\end{tabular}

\section{Focus Group}

Discussion

participants $^{2}$
- Bapak Wahyu (head of KSB); Bapak Yudi (head of village); Mas Joni (youth representative, farmer); Bapak Harjono (head of hamlet 1, farmer); Bapak Tukiman (head of hamlet 2, farmer); Bapak Sukur (head of hamlet 3, farmer); Bapak Imam (farmer); Bapak Sunarko (farmer)

\footnotetext{
${ }^{1}$ Focus group discussion; ${ }^{2}$ the names of informants are changed to protect their identity.
}

Areas covered by volcanic ash and fine rock material could not be planted with several crop types including potatoes and vegetables until 2 years after the eruptions. In the FGD, participating farmers explained that land in flat areas exacerbates the effect since volcanic material cannot be easy swept away by runoff. However, areas which were covered by ashes without fine rock material were more fertile 1 year after the time of eruption. Local communities were well aware of both the negative and positive effects on agricultural productivity. They referred to the increase of soil fertility as "Berkah Bromo" or Bromo's opportunity. Most people interviewed and farmers in particular stated that Bromo provides benefits for their livelihood.

Additional to the direct hazards from eruptions Mt. Bromo also generated secondary hazards such as volcanic mud flow (see Fig. 5), locally known as "lahar hujan" (lava rain). Particularly areas located at the foothills of the volcano were affected by this source of hazard. More than 20 houses collapsed due to lahar hujan (Bachri et al., 2013a). Heavy rainfall and flooding of the river Badesh caused volcanic deposits from Mt. Bromo to be activated and flow as lahar hujan. As a result, agricultural land and a number of buildings on the riverbanks were destroyed. Despite the negative effects of $l a$ har hujan in the short term, an increased agricultural productivity of the affected land can be observed and is appreciated as well as capitalized on by local people. One of the village heads informed us that: 
Table 3. Questions asked during semi-structured interviews and focus group discussion.

\begin{tabular}{|c|c|}
\hline Question & Rationale \\
\hline $\begin{array}{l}\text { Question about: Personal details } \\
\text { (name, age, education background, gender, } \\
\text { religion, occupation, members of family) }\end{array}$ & Socio-demographic \\
\hline Have you always lived in this village? & Local environmental \\
\hline $\begin{array}{l}\text { If yes, could you tell me about Bromo } \\
\text { and the surrounding area? }\end{array}$ & knowledge \\
\hline What is the meaning of Bromo in your life? & Life value, risk and benefits \\
\hline What is your ancestral story about Bromo? & Culture and folklore \\
\hline What is your experience of Bromo eruptions? & Memory, hazard knowledge \\
\hline What kind of hazards are you aware of? & Hazard knowledge \\
\hline And how is your area affected by them? & \\
\hline $\begin{array}{l}\text { Please tell me about Bromo's hazard zones? } \\
\text { Is your village categorized as hazard } \\
\text { prone area? }\end{array}$ & $\begin{array}{l}\text { Hazard and local } \\
\text { environmental knowledge }\end{array}$ \\
\hline And how about other villages? & \\
\hline $\begin{array}{l}\text { Think about the last eruption, how } \\
\text { dangerous was this eruption for you? } \\
\text { Do you dread Bromo? } \\
\text { Please share your feelings. }\end{array}$ & Risk perception \\
\hline $\begin{array}{l}\text { In your opinion, do you think that Bromo } \\
\text { will erupt again in the near future? Why? } \\
\text { Could you tell me signs for imminent } \\
\text { eruption? }\end{array}$ & $\begin{array}{l}\text { Risk perception, } \\
\text { Hazard knowledge }\end{array}$ \\
\hline
\end{tabular}

Wilayah yang terkena banjir lahar material bromo akan menjadi lebih subur setelah beberapa lama apabila kandungannya pasirnya tidak dominan

(translation.: Areas which are affected by lahar hujan from Bromo will be more fertile after some period if they are not dominated by sand materials).

Landslides were a further hazard that frequently occurred in Mt. Bromo's surrounding areas. The type of deposited material, slope steepness and heavy rainfall were the decisive factors for the occurrence of landslides. In some places, landslides had a severe impact particularly with regards to road accessibility. However in other areas landslides contributed to the soil quality by transferring fertile materials.

The Bromo eruptions in 2010 were also characterized by sulfur dioxide $\left(\mathrm{SO}_{2}\right)$ emissions. People living within an area of 5-7 km radius from the crater breathe these gas emissions. The effect on plantations was described by the head of one of the affected villages:

Di erupsi Bromo tahun 2010 desa saya hanya terkena dampak belerang, walau hanya satu hari saja kami merasakan bau itu, banyak tanaman mati khususnya kentang

(translation.: At the Bromo's eruption in 2010 my village was only affected by sulfur dioxide emissions and although we could feel them only for one day, many plantations died, particularly potatoes).

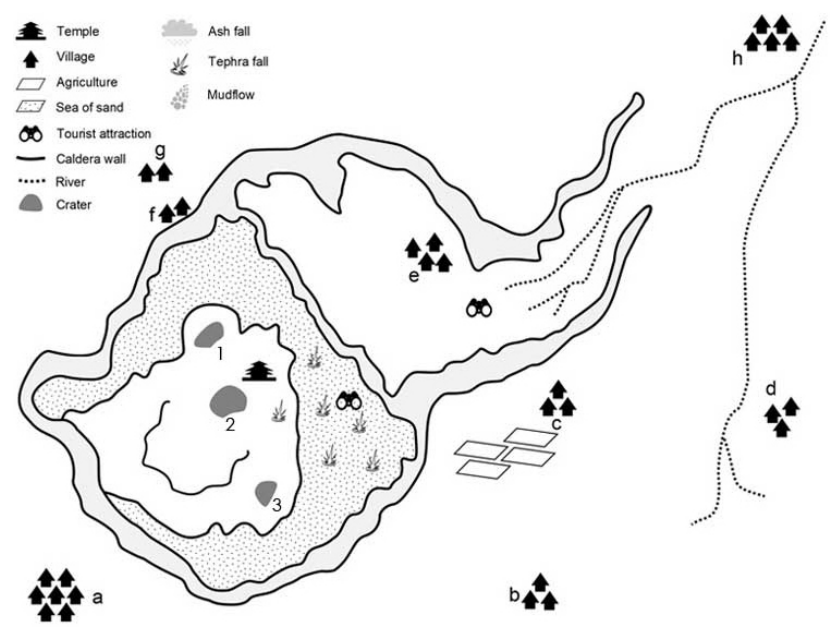

Figure 5. Human-volcano system at Bromo Volcano. (1) Mt. Batok, (2) Bromo Volcano, (3) Mt. Kursi, (a) Ngadas Village, (b) Ranupane Village, (c) Ngadirejo Village, (d) Sumber Village, (e) Ngadisari Village, (f) Wonokitri Village, (g) Tosari Village, (h) Wringinanom Village.

The four major hazards (gas emission, tephra falls/ballistic, landslides and volcanic mud flow) produced by Mt. Bromo's eruptions had affected the human system in general and human settlement, human health, daily life activities, tourism activity, trading and transportation system as well as agricultural properties in particular. The volcanic eruptions mostly had negative effects for a short period during and after the eruption. However, after the eruption period had come to an end, the community perceived and evaluated predominantly those effects that represented an opportunity. Agriculture, as the main livelihood of Tengger communities, offered favourable conditions as soon as 1-3 years after the end of the eruptions. While during the eruption period, farmers became unemployed and lost their land and crops they were able to capitalize on increased soil fertility after 1-3 years after the eruptions and thus were able to recover their losses.

\subsection{Social context}

The findings discussed above relate to the environmental impact of eruptions and the socio-economic knock-on effects. However, interviews with a number of informants and discussion in the FGD session show that the communities within the area interpret Mt. Bromo's eruptions not so much in specific terms of its environmental or socio-economic impacts but rather in its overarching cosmological meaning. Most people believe that Mt. Bromo always provides them with benefits for the continuity of their livelihoods and spiritual wellbeing. The "Tengger community" whose earliest settlements can be traced back to the 16th century (Hefner, 1990) has strong faith in the benevolence of the volcano and interprets its eruptions as a gift from God (see Fig. 6). 


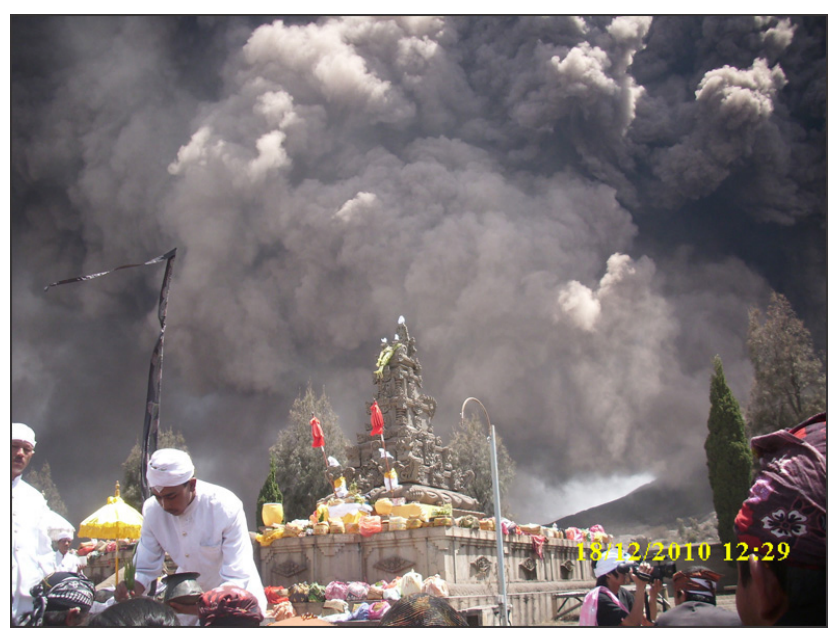

Figure 6. Religious ceremony at Puten temple inside the Tengger Caldera during the eruptions (Photo by Triono, 2010).

Hefner (1990) describes Mt. Bromo as the centre of the Tengger cosmology. This notion can be confirmed based on the interviews we conducted. For example a village official from Ngadirejo said:

\begin{abstract}
Saya tidak pernah takut akan letusan bromo karena saya selalu percaya bahwa ini adalah letusan yang bersifat sementara, dimana letusan itu selalu memberi berkah terhadap kami semua. Kami percaya bahwa Bromo selalu memberikan apa yang kami perlukan disini
\end{abstract}

(translation.: I am never scared of Bromo's eruption because I always believe that this is just temporary. Bromo's eruptions always benefit us. We believe that Bromo always gives us what we need to live here).

The fact that "only two careless foreigners" died in 2004 was seen as a confirmation of Bapak Rudi's views. There is a firm belief in Mt. Bromo's benevolence and that in return there must be a positive attitude towards the mountain.

Local people believe that Mt. Bromo will reflect the very attitude people have towards it:

\section{Jika kamu berbuat buruk terhadap Bromo ataupun hanya berpikiran negatif, maka Bromo akan mem- berikan situasi yang sama seperti yang kamu pikirkan}

(translation.: If you do bad things or even just think negatively about Bromo, Bromo will provide a negative situation),

says a village official from Ngadas. Supporting this view, a dukun in one of the affected villages adds the following:

Kita harus selalu berdoa yang terbaik untuk Bromo dan kehidupan disekitarny (translation.: We should always pray for the goodness of Bromo and its life surrounding).

An interview with a participant of the FGD session in Ngadirejo provides a local view, and thereby an understanding of the deep spiritual human-volcano relationship, on why the impact of the eruptions in 2010 was unusually severe for some villages within the Bromo area. He laments that the Tengger people did not do what their ancestors had told them. Before the eruptions, their agricultural yields were abundant, but most people, particularly the younger population, used their income to buy motorcycles and consumer gadgets even if not really needed. Traditional saving systems were ignored and abandoned. Consequently, a number of villages lacked the resources to cope with the period of eruptions. Incidentally these villages were particularly affected by the eruption. He explains that if ancestral laws are not observed Mt. Bromo will punish society accordingly. This perception was also confirmed by other participants of the FGD. It is a personified, directed threat of negative impacts that motivates disaster preparedness. The perception of the volcano as an animated being that interacts with and reacts to human behaviour underlies local adaptation strategies.

Apart from belief systems that link the local community with the volcano there is also intricate local knowledge of the physical environment that facilitates the interpretation of early warning signs of an imminent eruption. The interviews conducted revealed a number of such early warnings. For example an eruption may be imminent when excessive white smoke can be observed from the crater or when a stronger than usual odour of sulfur persists or when small volcanic tremors can be felt, particularly by people who live at or nearby the crater. Also, as one participant of a FGD, a farmer and youth representative from Ngadirejo village, states:

\section{Ketika tanaman jagung di tanah Mbako (lahan di lereng atas gunung tengger) mempunyai hasil yang bagus tetapi burung-burung menjauhi lereng tersebut, dapat dipastikan bromo akan meletus lagi \\ (translation.: When the corn crop in "Mbako" land [land at the upper slopes of the Tengger caldera] has good yields but birds stay away from the slopes, it can be sure that Bromo will erupt again).}

The Tengger community feels itself to be a part of the mountain. Land, water and forest of the mountain are the very source of their life, and thus the behaviour of Bromo is intricately linked to their life.

This perceived and lived interdependence with Mt. Bromo is shared among all members of the Tengger community and leads to the establishment of social networks that go beyond the village. For example Ngadirejo, a village that was severely hit by the 2010 eruptions, received assistance from Ngadas village despite being also impacted itself. Ngadas villagers provided goods such as rice and vegetables from 
their own agricultural land. Assistance went as far as offering their agricultural land to people from Ngadirejo for cultivation. When asked about this, our informants answered: "We, the Tengger people, are reminded by this eruption that we are one community. We must help each other. This eruption makes the bond between us become stronger". Thus the eruption strengthened the social fabric among Tengger people. While a spirit of community and altruism can often be observed in the aftermath of disasters it seems that here the disaster was a reminder of a pre-existing common spiritual link. The volcano was reinforcing the existing communal bonds that helped recovery.

The Tenggerese also exhibited a remarkable adaptive capacity to the circumstances during the eruption period. A farmer from Ngadirejo village explained that the eruptions generated considerable touristic interest toward the end of the eruption period and says:

\section{Kami sementara waktu berpindah pekerjaan dari bertani ke sektor wisata, karena pada saat itu tidak memungkinkan untuk kami mengolah tanah perta- nian kamu karena abu vulkanik. Pada akhirnya ini sangat bermanfaat bagi kami}

(translation.: We temporarily shifted our livelihoods from cultivating land to the tourism sector, because at that time we could not cultivate our agricultural land due to volcanic ash materials. At the end this was very favourable for us).

\section{Discussion}

The cited literature below tackles the question of how culture enables people to live with volcanic hazard. Cultural adaptations have been identified and put forward as explanations in many cases. We want to go beyond the question of how and ask why do people choose to live exposed to largely unpredictable hazard? Is this due to lack of alternatives or could it be indeed a free and deliberate choice? In the remainder of this section we argue that what has been identified as cultural adaptations to hazard can (a) enable a society to reap benefits produced by the hazardous processes and (b) be viewed as a good in itself for which, in order to obtain it, exposure to the hazard is vital.

\subsection{Socio-cultural benefits of volcanic risk}

Wherever they are in the vicinity of volcanoes, societies have fundamentally been shaped by recurrent eruptions. Belief systems and agricultural practice, mythology and social structure, traditions and politics are shaped, and more often than not, centred on the existence of potential volcanic hazard. A diverse body of literature shows that this holds true for societies that no longer exist (Cashman and Giordano, 2008; Plunket and Uruñuela, 2008, Paton et al., 2013) as well as being observed today the world over (Cashman and Cronin,
2008; Paradise, 2005; Gregg et al., 2008; Siswowidjoyo et al., 1997). Various disciplines analyse the multilayered relationship that exists between human societies and volcanic risk. Such work on the locally specific, societal element of disaster is particularly important in view of the dominant, overly Eurocentric and "technocratic" discourse on natural hazards (Bankoff, 2001, 2003). On the one hand, it is important to study the interrelation between people and their environment at a local level in order to shed light on how a combination of physical extremes and societal conditions can lead to disaster (Bankoff, 2003; Hewitt, 1983, 1997). On the other hand, a social and cultural perspective helps to understand how people have adapted to hazards and have learned to reap opportunities they are presented with. For example, anthropological research looks at the way that volcanism is embedded in mythology through the prism of geomythology. Natural events and human life - meaning the state of society - are always seen as being interconnected (Oliver-Smith, 1996; Schlehe, 1996, 2010). People "domesticate" the volcanic threat (Dove, 2008) and are surprisingly not scared (Lavigne et al., 2008) to live in its vicinity. Dove (2010) analyses the role of Mount Merapi in Java in the context of public opinion, power relations and political decision making in Java from a philosophical and historical-political perspective. Other authors, such as Donovan (2010) explore social volcanology, particularly culture, at Merapi volcano. Results show that a mixture of factors influences people to stay in the vicinity of Merapi volcano - these include cultural beliefs, such as safety provided by spiritual powers, the abundance of livestock and positive past experiences. In addition, studies on religious beliefs observe how the threat and fallout of volcanic hazard is interpreted and aligned with the divine. Here the principle of understanding natural hazard as punishment for sinful conduct is captured in the concept of theodicy (Wisner, 2010; Chester, 2005; Chester et al., 2008). For example, victims of volcanic hazards are seen as martyrs following Islamic interpretations of natural hazards. Chester et al. (2013) point out that this interpretation must not to be seen as complacent fatalism but rather as human humbleness. Recurrent eruptions fit well with cosmologies that understand destructive physical processes as new beginnings and part of the cyclical nature of all things (Heine-Geldern, 1956; Lüem, 1988; Chester, 2005). The cycle of destruction and creation that is so immediately manifest in recurrent volcanic eruptions resonates also in Christian religious adages if one thinks of the phrase from the Anglican burial service "ashes to ashes and dust to dust".

Contrary to the view that habitation in volcanic hazard zones is mostly a result of marginalization and economic pressure (Wisner et al., 2004; Lavigne et al., 2008), the results of our field work confirm what the cited literature implicitly suggests, that people choose to live with volcanic hazards because they are not only exposed to negative consequence but also reap the benefits and opportunities that arise within a human-volcano system. Within a human-volcanic 
system perspective the focus must be widened and include physical, social and cultural aspects that pertain to the entire system and go beyond eruptions and their immediate and detrimental consequences.

Volcanoes are a powerful force in shaping cultural identity. Rather than an environmental hazard to avoid at all costs, people's cultural identity is centrally inspired by "their volcano". The very essence of who the Tenggerese are revolves around the volcano, and without it they would culturally cease to exist. What Hewitt (1997) describes as the threat of "cultural annihilation" is turned on its head. Mt. Bromo does not threaten to destroy the Tenggerese, but the Tenggerese would be destroyed without Mt. Bromo. It is the potential for disaster itself that lies at the very basis of their cultural existence. By inspiring cultural identity the humanvolcano system produces socio-cultural benefits in direct and indirect form. These benefits emerge only to a lesser degree directly from eruptions. However, the pivotal and multidimensional role of the volcano within the system produces a range of system-strengthening and capacity-building outcomes. These revolve around social structure and position therein, as well as grounding through heritage and ancestral lineage. People gain their very place on Earth through the existence of the volcano (Schlehe, 1996).

In this sense it was at no surprise that in our analysis of semi-structured interviews and FGD we found an overwhelmingly positive attitude toward the Mt. Bromo eruptions. The positive aspects that are our focus here were developed during and after conducting the interviews when it became apparent how positive people's attitude towards Mt. Bromo really is. What follows is a list of cultural adaptations identified and amalgamated from the cited literature and reframed as socio-cultural benefits that in order to obtain, people may weigh against the cost of potential hazard. More than an adaptation to an adverse condition these sociocultural benefits are goods in themselves for which it becomes worthwhile to be exposed to hazard. In no particular order we propose the following five items as socio-cultural benefits stemming from the cultural identity of living within a human-volcano system.

\subsubsection{Resilience and capacity to recover}

Directly linked to cultural identity is the specific capacity of individuals and communities to recover from disaster (Paton et al., 2013). In the aftermath of a natural disaster a community's capacity to recover psychologically and spiritually is equally important as the ability to recover in a physical and economic sense (Chester, 2005). By occupying an important place in people's cosmology rather than being perceived as a mere fluke of nature, the hazardous volcano itself is at the basis for psychological and spiritual recovery. For example Schlehe (1996) observes a "sense of security through the spirit world" that is governed by the volcano, and further that supernatural metaphors, story-telling and culturally accepted forms of explaining loss all contribute to resilience. Thereby the volcano itself becomes the source of people's capacity to recover - it is curse and blessing simultaneously.

\subsubsection{Attachment to place and hazard knowledge}

Due to their distinctness and the relatively small spatial extents of human-volcano systems the volcano instils a local attachment to environment and place. This may lead to a heightened sense of stewardship and sustainable environmental resource management. The particular demands of the hazardous environment and resulting engagement with the volcanic system lead in turn to local knowledge and hazard management strategies.

\subsubsection{Social and moral order}

The interpretation of loss, destruction and suffering from volcanic hazard as a punishment for sinful conduct sent from the divine not only reconciles and justifies in the sense of theodicy but helps to uphold social and moral order. For example the threat of disaster is used to reinforce the prohibition of alcohol and prostitution (Schlehe, 1996; Chester et al., 2013).

\subsubsection{Means to frame and voice dissent}

The freedom to interpret natural events as a direct reflection of ills in society - such as for example unjust power relations, land ownership and corruption - enables people to frame and voice dissent safely and embedded in a larger cosmological setting. Oliver-Smith (1996) notes that "disasters create contexts in which power relations and arrangements can be more clearly perceived and confronted, which transforms political consciousness, shapes individual actions, and strengthens or dissolves institutional power arrangements."

\subsubsection{Catalyst for change processes}

Volcanic eruptions have been described as "agents of change" (Dove, 2008; Cashman and Giordano, 2008) in a physical as well as socio-political dimension. The perturbations of volcanic eruptions have brought about changes ranging from the economic basis of local livelihoods and settlement patterns to social organization and power relations. As noted by Dove (2008) these changes have often been for the good and are an integral part of the human-volcano system.

We argue that these socio-cultural benefits are, even where there is no direct physical relation nevertheless a consequential outcome of living with volcanic risk. They reflect an active choice to live exposed to volcanic hazards. Further, they can only be understood in a wider human-volcano system perspective that goes beyond geophysical analysis and traditional risk concepts in natural hazard research. 


\subsection{Risk and open-risk concept}

Traditionally scientific examinations of natural hazard processes were conducted from a pure natural scientific and engineering point of view not including societal aspects. The only way in which society was addressed if at all was in the role of a potential victim which had to be protected from losses. Although the principal idea of risk rooted in Medieval Mediterranean maritime trade is related to both potential profit and loss, this open understanding of risk no longer features in modern risk analysis (Banse, 1996; Fuchs, 2009). In lieu thereof, since 1950, risk concepts were developed in different disciplines in various contexts (Dikau and Weichselgartner, 2005; Müller-Mahn, 2007; Renn et al., 2007). The principal ideas of geographical hazard research (see e.g. White, 1964) may be seen as a forerunner to modern risk research. The introduction of aspects of human ecology (e.g. Burton et al., 1978), political ecology (e.g. Blaikie et al., 1994) and ideas of environmental justice (Cutter, 1996) to hazard research paved the way to a strengthening and further development to risk research. Focusing on flash floods, their perception and assessment, Kates (1962) and White (1964) introduced risk aspects into natural hazard research. Based on this approach, which integrated aspects of physical geography, social sciences and economics, a first comprehensive natural hazard risk analysis may be attributed to Petak and Atkinsson (1982). In recent years, process-oriented concepts have been replaced by a more sophisticated integrative risk management (e.g. Ammann, 2001; Stötter et al., 2002) or ideas towards a so-called risk society (e.g. Beck, 1992, 2009), risk culture or risk governance framework (e.g. International Risk Governance Council, 2005). However, similar to other natural hazard risks, volcanic risks remain to be connoted with negative impacts on society. But as shown in this paper, all these (traditional) risk perspectives cannot explain the perception and decision making in the Bromo humanvolcano system. Gaillard (2008) found in his research at Mt. Pinatubo that high perception of risk does not discourage people from living in hazard-prone areas. In this sense, only an open-risk concept (see e.g. Campbell and Vuolteenaho, 2004; Stötter and Coy, 2008) which allows including both potential positive and negative outcomes can help to explain the attitude of the local population in the Mt. Bromo region. On a theoretical level, in such open-risk concept, all future developments intrinsically exhibit some degree of uncertainty bearing options for both good risk, i.e. an opportunity to be grasped, and bad risk in the classical sense of a negative outcome to be avoided. Weighing positive against negative effects in the open-risk concept follows a similar rationale as the concept of cost-benefit analysis (e.g. Nas, 1996), which indeed became an instrument in natural hazard management by the US Flood Control Act of 1939 (see Guess and Farnham, 2000). It demanded that "the benefits to whomever they accrue [be] in excess of the estimated costs". But while in this approach human beings are understood as homo eco- nomicus the decisions of whom are primarily driven by economic, utilitarian reasoning, the open-risk concept goes far beyond that by considering also social, cultural, political and ecological aspects that cannot be monetized. A spiritual benefit can therefore outweigh a negative effect on for example physical infrastructure.

In a human-environment system, the linkage between impact and the exposed systems is generally determined by the sensitivity of the reacting system to the external impulse. That means that vulnerability and capacity, respectively resilience, are the interacting factors that govern the dimension of risk. In the Bromo human-volcano system, the local population perceives volcanic activity as source of both the threatening destructive forces as well as the agricultural basis of existence and spiritual home of their community. Based on their cultural system of values, in their interpretation, the good risks provided by Bromo Volcano do more than compensate the bad risks and thus they accept their living conditions in the Mt. Bromo area. The risk perception of the Tenggerese and their consequential behaviour is very similar to the understanding of Medieval merchants who first created the term "risco": the Tenggerese understand the gain of accepting risk with all its consequences. We suggest that a holistic understanding of risk, be it a forgotten Medieval concept or alive in local knowledge, must inspire the way in which we address an open and uncertain future. Modern, engineering-based risk research has provided us with practical tools of risk assessment, evaluation and monitoring. More recently societal aspects of natural hazard have widened our conceptualization of risk. Now it is time to reintroduce what is on the upside of the coin - the opportunities that humans sought whenever they chose to expose themselves to risks.

\section{Conclusions}

The empirical research discussed in this paper shows that the interaction between human and volcanic environment at Bromo Volcano is multifaceted and complex. The Tengger people of the Bromo area choose deliberately to live with volcanic hazards. They do so because they do not feel only exposed to negative consequences of volcanic hazards, but also enjoy benefits and opportunities of physical, socio-economic and spiritual nature that arise within the human-volcano system. We confirm five cultural adaptations as actual benefits originating from cultural life within the Bromo humanvolcano system - these are heightened resilience and capacity to recover; attachment to place and hazard knowledge; source of social and moral order; means to frame and voice dissent; and catalyst for change processes.

Following this perception, the concept of risk itself must be revisited. First, it must go beyond including socioeconomic aspects of risk. Second, it must be expanded from a one-sided focus on hazardous processes to a more holistic view of risk that includes the various positive aspects that 
pertain to the entire system, which cannot be fully understood within a simple exposure/vulnerability risk concept. The development of a generic human-volcanic system model could provide the basis for the development of an open-risk conceptual model.

Acknowledgements. The authors are grateful to DIKTI (Directorate General of Higher Education, Ministry of National Education of Republic Indonesia), who supported this research activity through a $\mathrm{PhD}$ scholarship, as well as to the University of Innsbruck, the State University of Malang and Gadjah Mada University for their support during field research and throughout the process of preparing the paper. The authors want to thank all contributors, i.e. Marshal Andriyan, Edwin Maulana, Puspita Indra Wardhani and Evi Dwi Lestari for their assistance during data collection in the Bromo area. We thank all informants for their permission of video-audio recording during interviews and paper publication. We also thank the local authorities at district level in East Java Province (Malang, Pasuruan, Probolinggo and Lumajang) especially Bapak Sanyoto and Bapak Kartono, mayors of Ngadirejo and Ngadas village respectively; the CVGHM (Centre for Volcanology and Geological Hazard Mitigation, Indonesia) especially Bapak Poniman and Mulyono; and the BPBD (Regional Agency of Disaster Management).

Edited by: A. Costa

Reviewed by: R. Nave and one anonymous referee

\section{References}

Abidin, H. Z., Andreas, H., and Gamal, M.: The deformation of Bromo volcano (Indonesia) as Detected by GPS Surveys Method, Glob. Positioning. Syst., 3, 16-24, 2004.

Ammann, W.: Integrales risiko management - der gemeinsame weg in die zukunft, Bündnerwald, 5, 14-17, 2001.

Andreastuti, S. D., Alloway, B. V., and Smith, I. E. M.: A detailed tephrostratigraphic framework at Merapi volcano, Central Java, Indonesia: implications for eruption predictions and hazard assessment, J. Volcanol. Geoth. Res., 100, 51-67, doi:10.1016/S0377-0273(00)00133-5, 2000.

Bachri, S., Stötter, J., and Sartohadi, J.: Bromo volcano area as human-environment system: interaction of volcanic eruption, local knowledge, risk perception and adaptation strategy, EGU General Assembly, Vienna, Austria, 7-12 April, EGU20133991, 2013a.

Bachri, S., Stötter, J., and Sartohadi, J.: Volcanic hazard assessment in Bromo volcano area, East Java (Indonesia), 8th IAG International Conferences on Geomorphology, Paris, France, 27-31 August, 2013b.

Bankoff, G.: Rendering the world unsafe: "Vulnerability" as western discourse, Disaster, 25, 19-35, 2001.

Bankoff, G.: Cultural of disaster: society and natural disaster in the Philippines, Routledge Curzon, London, 232 pp., 2003.

Banse, G.: Herkunft und Anspruch der Risikoforschung, in: Risikoforschung zwischen Disziplinarität und Interdisziplinarität, Von der Illusion der Sicherheit zum Umgang mit Unsicherheit, edited by: Banse, G., Sigma, Berlin, 15-72, 1996.
Beck, U.: Risk Society: Towards a New Modernity, SAGE Publications, London, 272 pp., 1992.

Beck, U.: World at risk, Polity Press, Cambridge, UK, 269 pp., 2009.

Bird, D. K., Gisladottir, G., and Dominey-Howes, D.: Volcanic risk and tourism in southern Iceland: Implications for hazard, risk and emergency response education and training, J. Volcanol. Geoth. Res., 189, 33-48, doi:10.1016/j.jvolgeores.2009.09.020, 2010.

Blaikie, P., Cannon, T., Davis, I., and Wisner, B.: At risk: natural hazards, people's vulnerability and disaster, Routledge, London, 284 pp., 1994.

BPBD (Badan Penanggulangan Bencana Daerah): Data damage and losses assessment pasca erupsi Bromo Tahun 2010, Probolinggo, Indonesia, 1-60, 2011.

BPS (Badan Pusat Statistik): Kabupaten dalam angka, Indonesia, 2011.

Bryant, R. L.: Power, knowledge and political ecology in the third world: a review, Prog. Phys. Geog., 22, 79-94, 1998.

Burton, I, Kates, R. W., and White, G.: The environment as hazard, Oxford University Press, New York, 240 pp., 1978.

Campbell, J. Y. and Vuolteenaho, T.: Bad Beta, Good Beta, Am. Econ. Rev., 94, 1249-1275, 2004.

Cashman, K. V. and Cronin, S. J.: Welcoming a monster to the world: Myths, oral tradition, and modern societal response to volcanic disasters, J. Volcanol. Geoth. Res., 176, 407-418, doi:10.1016/j.jvolgeores.2008.01.040, 2008.

Cashman, K. V. and Giordano, G.: Volcanoes and human history, J. Volcanol. Geoth. Res., 176, 325-329, doi:10.1016/j.jvolgeores.2008.01.036, 2008.

Chester, D. K.: Theology and disaster studies: The need for dialogue, J. Volcanol. Geoth. Res., 146, 319-328, doi:10.1016/j.jvolgeores.2005.03.004, 2005.

Chester, D. K., Duncan, A. M., and Dibben, C. J. L.: The importance of religion in shaping volcanic risk perception in Italy, with special reference to Vesuvius and Etna, J. Volcanol. Geoth. Res., 172, 216-228, doi:10.1016/j.jvolgeores.2007.12.009, 2008.

Chester, D. K., Duncan, A. M., and Al Ghasyah Dhanhani, H.: Volcanic eruptions, earthquakes and Islam, Disaster Prevention and Management: An International Journal, 22, 278-292, doi:10.1108/DPM-04-2013-0079, 2013.

Cutter, S. L.: Vulnerability to environmental hazards, Prog. Hum. Geog, 20, 529-539, 1996.

CVGHM (Centre for Volcanology and Geological Hazard Mitigation): Laporan penyelidikan pasca bencana letusan gunung api Bromo, Indonesia, 1-33, 2010.

De Bélizal, É., Lavigne, F., Gaillard, J. C., Grancher, D., Pratomo, I., and Komorowski, J.-C.: The 2007 eruption of Kelut volcano (East Java, Indonesia): Phenomenology, crisis management and social response, Geomorphology, 136, 165-175, doi:10.1016/j.geomorph.2011.06.015, 2012.

Descartes, R.: Meditationes de prima philosophia, Michael Soly, Paris, 116 pp., 1641.

Dikau, R. and Weichselgartner, J.: Der unruhige Planet: der Mensch und die Naturgewalten, Primus-Verlag, Darmstadt, 191 pp., 2005.

Donovan, K.: Doing social volcanology: exploring volcanic culture in Indonesia, Area, 42, 117-126, 2010. 
Dove, M. R.: Perception of volcanic eruption as agent of change on Merapi volcano, Central Java, J. Volcanol. Geoth. Res., 172, 329-337, doi:10.1016/j.jvolgeores.2007.12.037, 2008.

Dove, M. R.: The panoptic gaze in a non-western setting: selfsurveillance on Merapi volcano, Central Java, Religion, 40, 121127, doi:10.1016/j.religion.2009.12.007, 2010.

Duncan, A. M., Chester, D. K., and Guest, J. E.: Mount ETNA volcano: Environment impact and problems of volcanic prediction, Geograph. J., 147, 164-178, 1981.

Fischer-Kowalski, M. and Weisz, H.: Society as hybrid between material and symbolic realms: Toward a theoretical framework of society-nature interaction, Adv. Human Ecol., 8, 215-251, 1999.

Fisher, R. V., Heiken, G., and Hulen, J. B.: Volcanoes: Crucibles of change, Princeton University Press, Princeton, New Jersey, 336 pp., 1997.

Fuchs, S.: Mountain hazards, vulnerability, and risk- a contribution to applied research on human-environment interaction, University of Innsbruck, Innsbruck, Austria, 119 pp., 2009.

Gaillard, J.-C.: Alternative paradigms of volcanic risk perception: The case of Mt. Pinatubo in the Philippines, J. Volcanol. Geoth. Res., 172, 315-328, doi:10.1016/j.jvolgeores.2007.12.036, 2008.

Gerven, M. V. and Pichlert, H.: Some aspects of the volcanology and geochemistry of the Tengger Caldera, Java, Indonesia: eruption of a K-rich tholeiitic series, J. Southe. Asian Earth Sci., 11, 125-133, 1995.

Gregg, C. E., Houghton, B. F., Johnston, D. M., Paton, D., and Swanson, D. A.: The perception of volcanic risk in Kona communities from Mauna Loa and Hualālai volcanoes, Hawai'i, J. Volcanol. Geoth. Res., 130, 179-196, doi:10.1016/S03770273(03)00288-9, 2004.

Gregg, C. E., Houghton, B. F., Paton, D., Swanson, D. A., Lachman, R., and Bonk, W. J.: Hawaiian cultural influences on support for lava flow hazard mitigation measures during the January 1960 eruption of Kilauea volcano, Kapoho, Hawai'i, J. Volcanol. Geoth. Res., 172, 300-307, doi:10.1016/j.jvolgeores.2007.12.025, 2008.

Guess, G. and Farnham, P. G.: Cases in public policy analysis, Georgetown University Press, Washington D.C., USA, 367 pp., 2000.

Hefner, R. W.: Hindu Javanese: Tengger tradition and Islam, Princeton University Press, New Jersey, USA, 303 pp., 1990.

Heijmans, A.: Vulnerability: A matter of perception, Benfield Greig Hazard Research Centre, 34 pp., 2001.

Heine-Geldern, R.: Conceptions of state and kingship in Southeast Asia, no. 18, Southeast Asia Program, Department of Far Eastern Studies, Cornell University, Ithaca, NY, USA, 24 pp., 1956.

Hewitt, K.: Interpretations of calamity from the viewpoint of human ecology, Geogr. Rev., 74, 226-228, 1983.

Hewitt, K.: Region of risk: A geographical introduction to disaster, Longman, The University of Michigan, USA, 389 pp., 1997.

IRGC (International Risk Governance Council): Risk governance, Geneva, Switzerland, 1-156, 2005.

Itoh, H., Takahama, J., Takahashi, M., and Miyamoto, K.: Hazard estimation of the possible pyroclastic flow disasters using numerical simulation related to the 1994 activity at Merapi Volcano, J. Volcanol. Geoth. Res., 100, 503-516, doi:10.1016/S03770273(00)00153-0, 2000
Kates, R. W.: Hazard and choice perception in flood plain management, no. 78-79, Department of Geography, University of Chicago, USA, 151 pp., 1962.

Kelman, I. and Mather, T. A.: Living with volcanoes: The sustainable livelihoods approach for volcano-related opportunities, J. Volcanol. Geoth. Res., 172, 189-198, doi:10.1016/j.jvolgeores.2007.12.007, 2008.

Latour, B.: We have never been modern, Harvard University Press, Cambridge, UK, 168 pp., 1993.

Lavigne, F., De Coster, B., Juvin, N., Flohic, F., Gaillard, J.-C., Texier, P., Morin, J., and Sartohadi, J.: People's behaviour in the face of volcanic hazards: Perspectives from Javanese communities, Indonesia, J. Volcanol. Geoth. Res., 172, 273-287, doi:10.1016/j.jvolgeores.2007.12.013, 2008.

Lüem, B.: Wir sind wie der Berg, lächelnd aber stark: Eine Studie zur ethnischen Identität der Tenggeresen in Ostjava, Basel: Ethnologisches Seminar der Universität und Museum f ur Völkerkunde, Wepf \& Co AG Verlag, Basel, 243 pp., 1988.

Mei, E. T. W., Lavigne, F., Picquout, A., de Bélizal, E., Brunstein, D., Grancher, D., Sartohadi, J., Cholik, N., and Vidal, C.: Lessons learned from the 2010 evacuations at Merapi volcano, J. Volcanol. Geoth. Res., 261, 348-365, doi:10.1016/j.jvolgeores.2013.03.010, 2013.

Müller-Mahn, D.: Perspektiven der geographischen Risikoforschung, Geographische Rundschau, 59, 4-11, 2007.

Nas, T. F.: Cost-Benefits analysis: Theory and application, SAGE Publication, Thousand Oaks, CA, USA, 220 pp., 1996.

Oliver-Smith, A.: Anthropological research on hazards and disasters, Ann. Rev. Anthropol., 25, 303-328, 1996.

Paradise, T. R.: Perception of earthquake risk in Agadir, Morocco: A case study from a Muslim community, Global Environmental Change - Part B: Environ. Hazards, 6, 167-180, doi:10.1016/j.hazards.2006.06.002, 2005.

Paton, D., Okada. N., and Sagala, S.: Understanding preparedness for natural hazards: A cross cultural comparison, J. Integr. Disaster Manage., 3, 18-35, doi:10.5595/idrim.2013.0051, 2013.

Petak, W. J. and Atkisson, A. A.: Natural hazard risk assessment and public policy: anticipating the unexpected, Springer-Verlag, New York, 489 pp., 1982.

Plunket, P. and Uruñuela, G.: Mountain of sustenance, mountain of destruction: The prehispanic experience with Popocatépetl Volcano, J. Volcanol. Geoth. Res., 170, 111120, doi:10.1016/j.jvolgeores.2007.09.012, 2008.

Popper, K. R.: Objective knowledge: an evolutionary approach, Clarendon Press, London, UK, 380 pp., 1972.

Pratomo, I.: Klasifikasi gunungapi aktif Indonesia, studi kasus dari beberapa letusan gunungapi dalam sejarah, J. Geologi Indonesia, 1, 209-227, 2006.

Renn, O., Schweizer, P. J., Dreyer, M., and Klinke, A.: Risiko, Über den gesellschaftlichen/Umgang mit Unsicherheit, Oekam Verlag GmbH, München, Germany, 200 pp., 2007.

Schlehe, J.: Reinterpretations of mystical traditions, Explanations of a volcanic eruption in Java, Anthropos, 40, 391-409, 1996.

Schlehe, J.: Anthropology of religion: Disasters and the representations of tradition and modernity, Religion, 40, 112-120, doi:10.1016/j.religion.2009.12.004, 2010.

Siswowidjoyo, S., Sudarsono, U., and Wirakusumah, A. D.: The threat of hazards in the Semeru volcano region in East Java, Indonesia, J. Asian Earth Sci., 15, 185-194, 1997. 
Solikhin, A., Thouret, J.-C., Gupta, A., Harris, A. J. L., and Liew, S. C.: Geology, tectonics, and the 2002-2003 eruption of the Semeru volcano, Indonesia: Interpreted from high-spatial resolution satellite imagery, Geomorphology, 138, 364-379, doi:10.1016/j.geomorph.2011.10.001, 2012.

Stötter, J., Meiß1, G., Ploner, A., and Sönser, T.: Developments in natural hazard management in Alpine countries facing global environmental change, in: Global environmental change in Alpine regions, edited by: Steininger, K. and Weck-Hannemann, H., Edward Elgar, Cheltenham, UK, 113-130, 2002.

Stötter, J. and Coy, M.: Forschungsschwerpunkt Globaler Wandel - regionale Nachhaltigkeit, in: Innsbrucker Jahresbericht 20032007, edited by: Gesellschaft, I. G., Innsbrucker Geographische Gesellschaft, Innsbruck, Austria, 219-240, 2008.

Surono: The mitigation strategy of geological agency dealing with volcanic eruption in Indonesia (case study of 2010 Merapi eruption), International seminar on Thematic Geospatial Information of Natural Disaster, Yogyakarta, Indonesia, 30 July 2013, 5, 2013.

Tilling, R. I.: Volcano hazard, in: Volcanoes and the Environment, edited by: Mart, J. and Ernst, G., Cambridge University Press, USA, 55-90, 2005.

van Rotterdam-Los, A. M. D., Heikens, A., Vriend, S. P., van Bergen, M. J., and van Gaans, P. F. M.: Impact of acid effluent from Kawah Ijen crater lake on irrigated agricultural soils: Soil chemical processes and plant uptake, J. Volcanol. Geoth. Res., 178, 287-296, doi:10.1016/j.jvolgeores.2008.06.027, 2008.
Wardenga, U. and Weichhart, P.: Sozialökologische Interaktionsmodelle und Systemtheorien - Ansätze einer theoretischen Begründung integrativer Projekte in der Geographie?, Mitteilungen der Österreichischen Geographischen Gesellschaft, 148, 9-31, 2006.

White, G. F.: Choice of adjustment to floods, Dept. of Geography, University of Chicago, USA, 93-96, 1964.

Wisner, B.: Untapped potential of the world's religious communities for disaster reduction in an age of accelerated climate change: An epilogue \& prologue, Religion, 40, 128-131, doi:10.1016/j.religion.2009.12.006, 2010.

Wisner, B., Blaikie, P., Cannon, T., and Davis, I.: At Risk: Natural Hazards, people's vulnerability and disasters, Routledge, Taylor \& Francis, Cornwall, 447 pp., 2004.

Zaennudin, A.: The characteristic of eruption of Indonesian active volcanoes in the last four decades, J. Lingkungan dan Bencana Geol., 1, 113-129, 2010.

Zaennudin, A.: Perbandingan antara erupsi Gunung Bromo tahun 2010-2011 dan erupsi komplek Gunung Tengger, J. Lingkungan dan Bencana Geol., 2, 21-37, 2011.

Zierhofer, W.: Gesellschaft: Transformation eines Problems, BIS Verlag, Oldenburg, Germany, 20, 298 pp., 2002. 